\title{
The Urgency of Indonesian Literary Text Book in Indonesian Learning at SMP/MTs
}

\author{
Mujiwanto $^{1}$, Murtono $^{2}$, Irfai Fathurohman ${ }^{3}$ \\ \{201703046@std.umk.ac.id ${ }^{1}$, murtono@umk.ac.id ${ }^{2}$,irfai.fathurohman@umk.ac.id $\left.{ }^{3}\right\}$ \\ ${ }^{1,2,3}$ Faculty of Teaching and Education, Universitas Muria Kudus Gondang \\ Manis PO. BOX 53 Bae, Kudus, Central Java, Indonesia Phone (+62291) \\ 438229, Fax (+62291)437198
}

\begin{abstract}
There are two purposes of this study, firstly to find out the type of textbook used in indonesian language learning at smp/mts and secondly to find out the design of literary learning in indonesian learning at smp/mts. This research method uses qualitative descriptive methods. Data obtained from interviews and observations. Data processing was done by analyzing the data collected, namely the learning literature observation sheet. The results of this study were that most teachers need a special textbook containing literary material as a complement to the textbooks (compulsory) published by the Ministry of Education and Culture. Literary learning in SMP/MTs is still constrained by the lack of literary material in Indonesian language textbooks.
\end{abstract}

Keywords: textbooks, literary, learning.

\section{Introduction}

The teaching and learning process always requires adequate facilities and infrastructure. One of the main tools in supporting the process is the book. Books are part of the continuity of learning. Teachers can manage learning activities effectively and efficiently by means of books. Books can also help maximize the effectiveness of student learning. One type of book that is commonly used in the learning process is a textbook. Textbooks are classified into two namely mandatory textbooks and supporting textbooks. Mandatory text books are textbooks published by the government (Ministry of Education and Culture) which are also called textbooks. While supporting textbooks are textbooks published by private parties both written by individuals and groups. Textbooks mandatory are published and enforced nationally, for that in terms of content is more general. Therefore, supporting textbooks are needed that are able to complement the lack of mandatory textbooks.

Textbooks provided by the government are in accordance with the names of subjects that have been determined according to the curriculum structure of each level of education. In this case, for the Junior High School/Madrasah Tsanawiyah level, Indonesian textbooks have been provided. In Indonesian language lessons are also taught literature. However, so far there has been no textbook that specifically contains material and literary learning.

Based on observations made by researchers at MTsN 1 Pati, data were obtained that the Indonesian textbooks used were for grade VII using the 2016 revised edition of the Ministry of Education and Culture textbook, the 2016 revised edition of the Marbi textbook, and the revised edition of Intan Pariwara textbooks 2016; for grade VIII using the 2017 revised edition textbook of the Ministry of Education and Culture, the 2017 revised edition of Marbi textbook, and the revised edition edition of Intan Pariwara 2017; and grade IX uses textbooks 
published by the Ministry of Education and Culture 2018 revised edition and textbooks published by Intan Pariwara 2018 revised edition. Especially textbooks published by Intan Pariwara are only used by teachers as companions to mandatory textbooks. So there is no textbook that specifically covers literary material to support Indonesian language learning.

Literature is a form of art that uses language as its delivery medium. Literature is an inseparable part of Indonesian language learning materials in SMP/MTs. There is a tendency for teachers and students to assume that literature is an exclusive material that can only be learned by talented people or writers. This is what causes literary learning to experience a gap. For this reason, appropriate media (textbooks) are needed so that learning runs better. This is because literary learning cannot be separated from language learning, and vice versa. Literature must be taught comprehensively with language skills, ranging from listening, speaking, reading, writing, and appreciation.

Literature has various genres and subgenres. Literature that is taught at the Middle School /Madrasah Tsanawiyah level broadly includes poetry, prose, and drama. For students, literature is a work of art that will hone the imagination and free students to expression. Literary learning that seems informal can make students seem not to be in learning activities. Therefore, proper literary learning with appropriate media and sources is able to explore and express students' talents, interests and creativity. This often happens in learning to write literature.

Curriculum 2013 has been implemented since 2014 and implemented nationally since 2016. One form of government readiness for the implementation of the curriculum is the publication of student books (textbooks) and teacher books as a means of learning. One of the things that is complained by the teacher is that the textbooks contain less material so that a textbook is needed as a companion and complement to the textbooks. This is in line with what was revealed by Purwanta (2012: 424) that today the position of textbooks is becoming increasingly central in the teaching and learning process because teachers find it difficult and hard to develop their own subject matter, either because of limited time or external pressure. These obstacles are also experienced by teachers who teach in SMP/MTs, especially in learning literary material. Because there are differences in the 2013 curriculum with the previous curriculum, among others, the simplification of the material, the addition of class hours, and so forth.

To obtain concrete data on this problem the researchers conducted field observations and interviews with teacher sources on Friday, April 26, 2019 at the Madrasah Tsanawiyah Negeri 1 Pati located in the Winong District area. Based on these observations, data obtained with the implementation of the 2013 curriculum caused teachers difficulties in adjusting, both in the readiness of teaching and in the readiness of teaching materials. Teachers are required to have extensive knowledge in all materials, while textbooks from the government only provide simple material. So, what many teachers experience is the difficulty in delivering deeper material in each subject. That is caused by the limited new material and supporting media, especially in the literature learning material in Indonesian subjects. The introduction of material to examples in literature learning causes the teacher difficulty in finding books that are suitable with the material and grade level of students.

From the problems above, the researcher concludes that literary textbooks are really needed in junior high schools. In learning literature, teachers and students often encounter difficulties, such as gaining material on various literary genres, finding similarities between literary differences, writing or producing literature, reading literature, listening to literature, staging literature, appreciating literature and many other difficulties. The use of textbooks is needed to make it easier for teachers to deliver learning materials and make it easier for 
students to accept learning materials delivered by teachers. However, the use of textbooks that discuss literature specifically is still rare so that teachers and students have difficulty in learning.

There are two purpose of this study, firstly to find out the type of textbook used in Indonesian language learning at SMP/MTs and secondly to find out the design of literary learning in Indonesian learning at SMP/MTs.

There are two benefits of this study; first the theoretical benefit of describing the types of textbooks in learning Indonesian; the second practical benefit is as material in improving literary learning in SMP/MTs.

\section{The Nature of Literature Textbooks}

Textbooks are the main operational tools for curriculum implementation and nontextbooks are a supporting tool to facilitate the implementation, assessment, and development of learning for students and educators so they must meet the criteria for books suitable for use by education units (Permendikbud No. 8 2016).

One of the books in the world of education is a textbook. Textbooks have a very important role for the advancement of education. Textbooks are books that contain material about specific subjects or fields of study, which are arranged systematically and have been selected based on specific objectives, learning orientation, and student development to be assimilated (Muslich, 2010: 50).

Meanwhile, Kustanto and Hinduan (2009: 3) state that text books can be defined as sources of information arranged in structure and order based on certain fields of science.

Warso (2016: 38) revealed that, textbooks are learning materials that are prepared and presented in writing so that readers are expected to absorb the material themselves. Textbooks are created by making an issue of real problems in the field of formal education at an educational level.

Based on some of these opinions, it can be concluded that textbooks are books in the field of education that function as sources of information or written teaching material in the form of materials used in units of basic education to higher education, arranged according to the structure and order of certain fields of science aimed at facilitating the learning process .

Thus, literary textbooks are books that contain literary material as a source of information or teaching material used in the basic education units to tertiary education, arranged according to the structure and order of the field of literature which aims to facilitate the learning process.

\section{Characteristics of Textbooks}

As has been explained in general, a text book is a printed teaching material used in a learning activity with the aim of helping understanding learning material. Characteristics of textbooks in general as stated by Muslich (2010: 60) as follows:

1. In terms of content. Textbooks contain a range of knowledge or information that can be accounted for by scholarship.

2. In terms of presentation. The material contained in the textbook is presented by following certain patterns of reasoning, as the patterns of reasoning in scientific offerings, namely patterns of inductive reasoning, deductive, or combination (inductive-deductive).

In terms of format. Textbooks follow the conventions of scientific books, both writing patterns, quotation patterns, distribution patterns, and discussion patterns.

In addition to the features above, textbooks also have a purpose for making. Textbooks are made based on the needs of teaching materials in schools. A good textbook is a textbook that 
is in accordance with the demands of the curriculum by considering the needs of students, so that according to the characteristics of students and the social environment of students. Thus the textbook will help students in obtaining alternative teaching materials in addition to the available text books. In addition, textbooks can also facilitate teachers in carrying out learning.

Textbooks become an alternative in learning activities. Making textbooks will provide many benefits such as students getting teaching materials in accordance with the curriculum, students do not depend on textbooks that are available only, students become richer in knowledge with more references, and many other benefits obtained.

\section{Method}

The method used in this research is descriptive qualitative. This research was carried out in MTs Negeri 1 Pati, Winong District. The subjects of the study were five Indonesian language teachers and Grade VII A students of MTs Negeri 1 Pati. Data collection techniques in this study were carried out through interviews and observations.

Interviews in this study were addressed to five Indonesian language teachers at MTs Negeri 1 Pati. The interview technique is to obtain data on the needs of literary textbooks. Meanwhile, observations were made to grade VII A students of MTs Negeri 1 Pati to obtain data on the conditions of literary learning in Indonesian language lessons.

\section{Results and Discussion}

Based on the interview results it is known that teachers need teaching materials in the form of textbooks that specifically contain literary material for SMP/MTs in order to support Indonesian language learning especially literary material to be more effective, interesting, and enjoyable. Most of the teachers stated that they had difficulty in obtaining sufficient material and examples of literary texts for the deepening of literary learning. While a small number of teachers consider that literary material is just ordinary material like other text material in learning Indonesian. The results of the guided interview about the need for literary textbooks as in the following table.

Table 1. The Need for Literature Textbooks as Indonesian Language Learning Materials

\begin{tabular}{|c|c|c|c|}
\hline Indicator & $\begin{array}{c}\text { Number } \\
\text { of } \\
\text { Teacher }\end{array}$ & Answers & $\begin{array}{l}\text { Intensity } \\
\text { of } \\
\text { Answers } \\
\end{array}$ \\
\hline \multirow{3}{*}{$\begin{array}{l}\text { Teacher's opinion on the presence } \\
\text { of Literature textbooks }\end{array}$} & 5 & is very important & 3 \\
\hline & & Important & 1 \\
\hline & & Less important & 1 \\
\hline \multirow{3}{*}{$\begin{array}{l}\text { Teacher expectations } \\
\text { textbooks used by teachers in } \\
\text { learning literature }\end{array}$} & 5 & $\begin{array}{l}\text { Text books that provide complete } \\
\text { literature material. }\end{array}$ & 5 \\
\hline & & $\begin{array}{l}\text { Interspersed with illustrations that } \\
\text { facilitate imagination. }\end{array}$ & 1 \\
\hline & & $\begin{array}{l}\text { Includes examples of literary texts, } \\
\text { more than one text and based on local } \\
\text { wisdom. }\end{array}$ & 4 \\
\hline
\end{tabular}


The table shows the teacher's opinion on the importance of textbooks: 3 out of 5 teachers or $60 \%$ of teachers consider the presence of literary textbooks to be very important, 1 in 5 teachers or $20 \%$ of teachers consider the presence of important literary textbooks, and 1 in 5 or $20 \%$ of teachers consider the presence of literary textbooks is not important. Whereas the teacher's expectation of the textbooks used in literary learning that is, 5 teachers or $100 \%$ of teachers want textbooks that present complete literary material, 1 teacher or $20 \%$ of teachers want textbooks interspersed with illustrated images so as to facilitate imagination, 4 out of 5 teachers or $80 \%$ of teachers want textbooks that include more than one sample of literary texts and are based on local wisdom, and 3 out of 5 teachers or $60 \%$ of teachers want textbooks that help guide the production of literary texts. Based on the explanation, the researcher can conclude that the presence of literary textbooks in learning Indonesian in SMP / MTs is very necessary.

The results of observation of literary learning in class VII A (excellent) MTsN 1 Pati showed a variety of responses and activities of students and teachers namely 1)learning took place well, 2)most students were able to understand literary material well, 3)some students were able to appreciate literature, and 4)some students are able to produce literature. Observation results also show some obstacles in learning in class, namely 1) some students are lazy to read, 2)some students are not interested, and 3)some students have difficulty in appreciating literature. Based on these observations, researchers can conclude that appropriate media and design are needed so that literary learning becomes more effective, interesting, and enjoyable so that learning objectives can be achieved optimally.

From the results of interviews and observations it can be concluded that literary textbooks are needed by teachers and students to support the effectiveness of learning, facilitate understanding, enrich and deepen the material, and increase students' reading motivation. This is in line with Contesa's research (2018) that the development of the textbook has a potential influence in improving the ability of students to understand Indonesian language material through examples, summaries, and exercises.

\section{Conclusions}

Literary textbooks are books that contain literary material as a source of information or teaching materials used in the basic education units to tertiary education, arranged according to the structure and order of the field of literature which aims to facilitate the learning process.

The results of interviews with the Indonesian language teacher MTsN 1 Pati showed the urgency of a literary textbook that 1) contained complete literary material, 2)included examples of literary texts, more than one text and based on local wisdom, and 3)helped guide the production of literary texts. Meanwhile, the results of observations of learning shows that there are obstacles in learning literature without the existence of literary textbooks, namely 1)some students are lazy reading, 2)some students are not interested, and 3)some students have difficulty in appreciating literature.

\section{Suggestions}


Based on the discussion, the researcher suggested that this research should be continued with research and development literature and textbook based on local wisdom literature.

\section{References}

Contessa, Emillia. 2018. Pengembangan Buku Teks Pragmatik Program Studi Bahasa, Sastra Indonesia, dan Daerah. Jurnal Bindo Sastra. Volume 2 (1).

Kustanto, Hery dan A. Hinduan. 2009. Kecenderungan Buku Teks Fisika Lama dan Buku Teks Fisika Baru untuk SMA. Tesis. Yogyakarta: Program Pasca Sarjana Pendidikan Fisika UAD.

Muslich, Masnur. 2010. Textbook Writing: Dasar-dasar Pemahaman, Penulisan, dan Pemakaian Buku Teks. Yogyakarta: Ar-ruzz Media.

Purwanta, Edi. 2012. Buku Ajar Bimbingan dan Konseling Anak Berkebutuhan Khusus. Yogyakarta: UNY Press.

Warso, Agus Wasisto Dwi Doso. 2016. Publikasi Ilmiah Pembuatan Buku, Modul, Diktat \& Nilai Angka Kreditnya. Yogyakarta: Putaka Pelajar. 